\title{
Studies on the genetic and non-genetic (physiological) variation of human erythrocyte glutamic oxaloacetic transaminase
}

\author{
BY K. H. WURZINGER AND H. W. MOHRENWEISER \\ Department of Human Genetics, University of Michigan Medical Center, Ann Arbor, MI 48109
}

\section{SUMMARY}

The thermostability profile of seven different electrophoretic variants of human erythrocyte GOT found in 13 different, unrelated families from a racially heterogeneous population was examined. The five different slow-variant and the two different fast-variant classes could be grouped into four different thermostability classes which were termed unstable, less stable, normal and more stable than normal. The thermostability differences among and within the electrophoretic variant classes permitted differentiation of the 13 individuals possessing an electrophoretic variant phenotype into a total of ten different variants.

\section{INTRODUCTION}

Human erythrocyte glutamic oxaloacetic transaminase (GO'T; E.C. 2.6.1 .1 ; aspartate aminotransferase) is a dimeric enzyme which catalyses the reversible reaction of L-aspartate and $\alpha$-ketoglutarate to glutamate and oxaloacetate and requires pyridoxal phosphate as an obligatory cofactor (Jenkins, Yphantis \& Sizer, 1959). Although both mitochondrial and cytoplasmic forms of the enzyme exist in animal, including human, tissues, only the cytoplasmic or soluble form occurs in the enucleated erythrocyte (Nisselbaum \& Bodansky, 1964; Wada \& Morino, 1964). Genetic variants of the soluble enzyme are relatively rare and have been described primarily from certain mongoloid populations, which, in addition to the common allele, contain two different electrophoretically identifiable alleles (Chen \& Giblett, 1971; Ishimoto \& Kuwata, 1974; Teng et al. 1978; Scott \& Wright, 1981). These alleles occur at low frequencies, usually in heterozygous combination with the normal allele.

In this paper we report some observations resulting from studies on normal and ten different electrophoretic and thermostability variants of human erythrocyte GOT discovered in 13 families in various racial/ethnic groups.

\section{MATERIALS AND METHODS}

The study population consisted of all infants born at the University of Michigan Women's Hospital between January 1977 and January 1981 whose parents agreed to donate blood samples. The sample from the newborn infants was obtained from the umbilical cord at delivery, and from the parents by venipuncture. All samples were collected with ACD as the anticoagulant. For certain experiments, blood collected from various laboratory personnel served as controls. The erythrocytes were washed three times with saline and stored as packed cells in liquid nitrogen. Haemolysates for electrophoresis were prepared by diluting 1 volume of packed cells with 1 volume of distilled $\mathrm{H}_{2} \mathrm{O}$ and extracting with 0.5 volume of toluene (Chen 
et al. 1971). The stroma was removed by centrifugation at $20000 \mathrm{~g}$ for $20 \mathrm{~min}$. Haemolysates for the activity and thermostability studies were prepared by diluting 1 volume of packed cells with 9 volumes of buffer (50 mM-HEPES ( $N$-2-hydroxethyl piperazine- $N$-2-ethansulphonic acid), $2 \mathrm{~mm}$ dithiothreitol, $1 \mathrm{~mm}$-EDTA, and $0.05 \%$ Triton-X 100, $\mathrm{pH} \mathrm{7.2)} \mathrm{and} \mathrm{centrifuging} \mathrm{at}$ $40000 \mathrm{~g}$ for $30 \mathrm{~min}$.

Enzyme activity and haemoglobin were assayed as described by Fielek \& Mohrenweiser (1979) and Beutler (1975) utilizing a Beckman DU spectrophotometer equipped with a temperature controlled Gilford automatic cuvette positioner and chart recorder. The units of activity are $\mu$ mole of product formed $/ \mathrm{g}$ haemoglobin $/ \mathrm{min}$ at $30^{\circ} \mathrm{C}$. Activity was measured in the presence of pyridoxal-5-phosphate following a $10 \mathrm{~min}$ preincubation period in reaction mix without $\alpha$-ketoglutarate. The reaction was started by addition of $\alpha$-ketoglutarate.

The thermostability studies were performed as outlined by Satoh \& Mohrenweiser (1979) and Mohrenweiser \& Neel (1981). The samples were incubated at $63^{\circ} \mathrm{C}$ and $67^{\circ} \mathrm{C}$ for varying times and/or for $20 \mathrm{~min}$ at varying temperatures between $63^{\circ} \mathrm{C}$ and $78{ }^{\circ} \mathrm{C}$.

Vertical starch gel electrophoresis, utilizing either $12.5 \%$ or $16 \%$ (w:v) Electrostarch (Otto Hiller, Madison, Wisconsin), was performed at $4{ }^{\circ} \mathrm{C}$ for $18 \mathrm{~h}$ using the equipment described by Brewer (1970). Five different buffer systems were employed. Electrophoretic system I was a

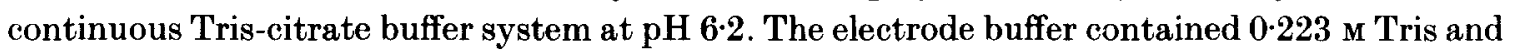
$0.086 \mathrm{M}$ citric acid (monohydrate). The gel buffer contained $35 \mathrm{ml}$ of electrode buffer diluted to 11 with distilled $\mathrm{H}_{2} \mathrm{O}$. Electrophoretic system II was a continuous Tris-citrate buffer system at $\mathrm{pH} 7 \cdot 0$. The electrode buffer contained $0 \cdot 155 \mathrm{~m}$ Tris and $0.043 \mathrm{~m}$ citric acid. The gel buffer was a 1:15 dilution of electrode buffer. Electrophoretic system III was a discontinuous buffer system at $\mathrm{pH} \mathrm{7.5}$. The electrode buffer contained $0.44 \mathrm{~m}$ boric acid, $0.04 \mathrm{~m}$ Tris and $0.04 \mathrm{~m}$ lithium hydroxide. The gel buffer contained $0.0124 \mathrm{M}$ Tris, $0.0036 \mathrm{M}$ boric acid, $0.0033 \mathrm{M}$ eitric acid and $0.00033 \mathrm{M}-\mathrm{LiOH}$. Electrophoretic system IV was the continuous Tris-citrate II buffer system at $\mathrm{pH} 8.0$ of Selander et al. (1971) and electrophoretic system $\mathrm{V}$ was the discontinuous Tris-citrate/borate buffer system of Poulik (1957).

All samples were first screened for GOT variants with electrophoretic system I. In order to distinguish possible microheterogeneity within the various electrophoretic classes detected during the initial screening, all variants were subsequently electrophoresed on the four additional buffer systems indicated above.

Following electrophoresis, the gels were sliced and stained for GOT activity. The staining solution was modified from Banks et al. (1968) and contained $400 \mathrm{mg}$ L-aspartic acid, $100 \mathrm{mg}$ $\alpha$-ketoglutaric acid, $5 \mathrm{mg}$ pyridoxal-5-phosphate and $500 \mathrm{mg}$ tetrazotized o-dianisidine dissolved in $400 \mathrm{ml}$ of $0 \cdot 2 \mathrm{~m}$ Tris-HCl, $\mathrm{pH} 8 \cdot 0$.

The electrophoretically identifiable variant alleles were assigned relative mobilities according to the system devised by Ayala et al. (1972). This system defines the mobility of the normal or reference allele as 1.00 . The distance in $\mathrm{mm}$ that the mobility of a variant differs from that of the reference allele is then added to or deducted from 1.00 to give the final variant allele mobility (Table 1). 
Table 1. Mobilities of the erythrocyte GOT variant electromorphs relative to the mobility of the common electromorph

$\begin{array}{cccc}\text { Allele } & \text { Mobility } & \begin{array}{c}\text { Buffer } \\ \text { system }\end{array} & \begin{array}{c}\text { Number of } \\ \text { individuals }\end{array} \\ \text { 3A } & 0.82 & \text { III } & \text { I } \\ \text { 3B } & 0.83 & \text { III } & \text { I } \\ \text { 3C } & 0.84 & \text { III } & \text { I } \\ \text { 3D } & 0.86 & \text { III } & \text { I } \\ \text { 3E } & 0.96 & \text { III } & \text { I } \\ \text { Normal } & \text { I.00 } & \text { II } & - \\ \text { 2A } & \text { I.1 } & \text { II } & 5 \\ \text { 2B } & \text { I.15 } & \text { II } & 3\end{array}$

RESULTS

A total of 2219 cord blood samples and approximately 70 blood samples from Department of Human Genetics Laboratory personnel were screened for GOT variants. The ethnic distribution within the study population was $85 \%$ White, $10 \%$ Black, $1 \%$ Oriental and $4 \%$ unidentified or other. Seven different electrophoretic variants distributed among 13 different unrelated families in various racial/ethnic groups were ultimately resolved on starch gels (Fig. 1). The primary allozymes of the various phenotypes are depicted schematically in Fig. 2. The affected individuals were heterozygous for the common plus a variant allele.

The normal phenotype of erythrocyte GOT consists of a single, anodally migrating electromorph accompanied occasionally by a slightly faster, minor band. Depending on the buffer system employed, additional, faster migrating bands may be generated. The individuals with the variant phenotypes all possessed a 3 -banded pattern of activity characteristic of dimeric enzymes. The mobilities of the variant electromorphs are indicated in Table 1.

Following the nomenclature of Chen \& Giblett (1971) the variants with mobilities faster (more anodal) than the normal phenotype are designated as type 2 variants, whereas variants with mobilities slower (less anodal) than normal are designated as type 3 variants. Electrophoretic variants within the fast and slow classes are designated by letter and thermostability variants within an electrophoretic class are designated by an additional number.

We believe that alleles $3 \mathrm{~A}$ and $2 \mathrm{~A}$ correspond to the slow and fast alleles of Chen \& Giblett (1971) since they occurred in individuals of Oriental ancestry. The other variants appear not to have been previously described.

During the initial electrophoretic screening which was conducted at $\mathrm{pH} 6 \cdot 2$ only four different (i.e. two different fast and two different slow) variant phenotypes were recognized. When it became apparent that thermostability differences existed within the various electrophoretic classes, all variants were re-electrophoresed on four additional buffer systems between $\mathrm{pH} 7 \cdot 0$ and $\mathrm{pH} 8.7$ in an effort to obtain further resolution. The two slow phenotypes (5 individuals) originally recognized at $\mathrm{pH} 6.2$ were thus differentiated into five different electrophoretic variants at $\mathrm{pH} 7 \cdot 5$. No electrophoretic differences within each of the two classes of fast variants were discerned in the $\mathrm{pH}$ range investigated with the five buffer systems employed in this study. Electrophoretic system II at $\mathrm{pH} \mathbf{7 \cdot 0}$, however, gave optimum separation of these two electrophoretic phenotypes. 

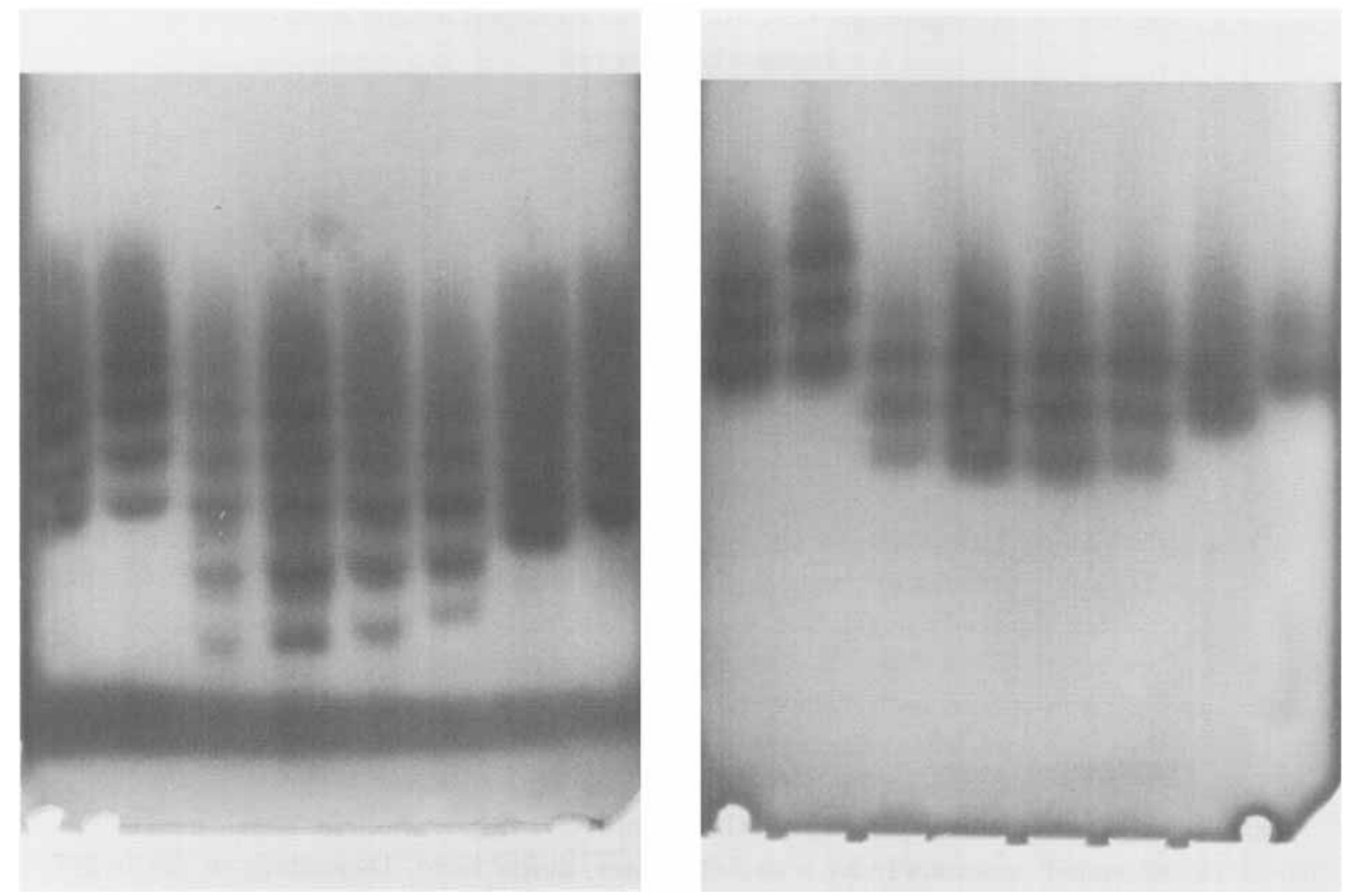

Fig. 1. Starch gel electrophoretic pattern of normal and seven different electrophoretic variant ery throcyte GOT phenotypes at pH 7.5 (Fig. $1 \mathrm{~A}$ ) and at pH 7.0 (Fig. $1 \mathrm{~B}$ ). The same samples are present on both gels. Well $1: 1 / 2 \mathrm{~A}$; well $2: 1 / 2 \mathrm{~B}$; well $3: 1 / 3 \mathrm{~A}$; well $4: 1 / 3 \mathrm{~B}$; well $5: 1 / 3 \mathrm{C}$; well $6: 1 / 3 \mathrm{D}$; well $7: 1 / 3 \mathrm{E}$; well $8: 1 / 1$.

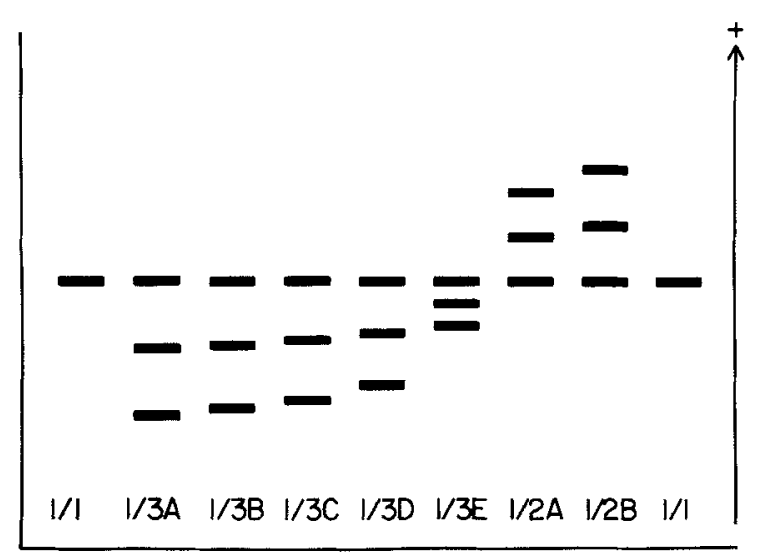

Fig. 2. Composite schematic representation of the common and the seven different electrophoretic variant phenotypes of erythrocyte GOT. Only the primary allozymes are illustrated. 


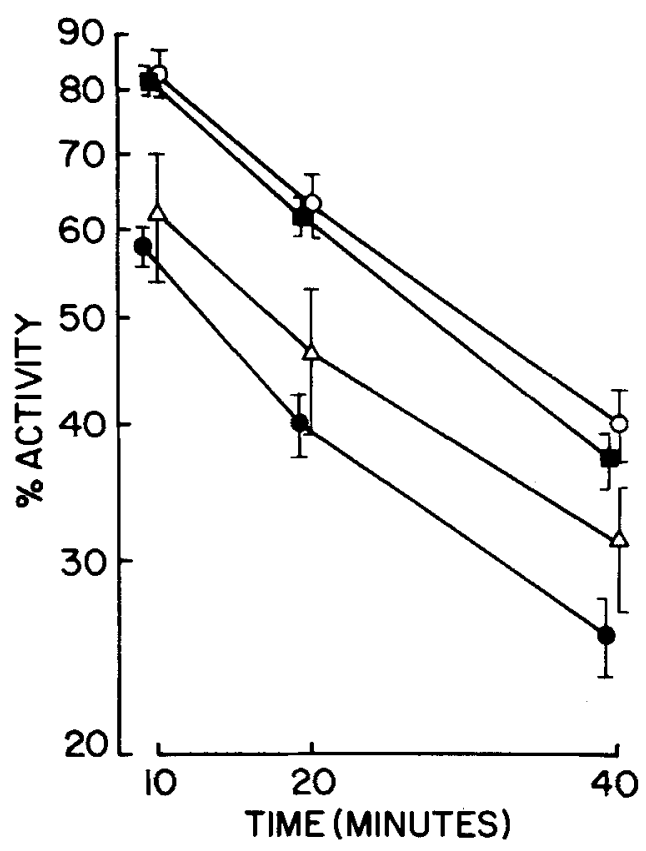

Fig. 3. Thermostability profile at $67^{\circ} \mathrm{C}$ of the common erythrocyte GOT phenotype from different sample sources. $(\bar{X} \pm$ s.c.) $O-O$ pregnant females, $\square-\square$ cord bloods, $\triangle-\triangle$ non-pregnant females, - males.

\section{Thermostability}

The erythrocyte GOT (common phenotype) from both cords and pregnant females was relatively thermostable compared to the enzyme from males and non-pregnant females (Fig. 3 ). The time for $50 \%$ inactivation (T-0.5) at $67^{\circ} \mathrm{C}$ was $31 \mathrm{~min}$ for the enzyme from pregnant females and $28.5 \mathrm{~min}$ for the cord blood enzyme. This contrasts sharply to the values for the enzyme from non-pregnant females $(17.5 \mathrm{~min})$ and males $(13.5 \mathrm{~min})$.

The T- 0.5 values for the cord blood electrophoretic variants ranged from a low of $14.5 \mathrm{~min}$ to a high of $40 \mathrm{~min}$. Thus, several of the variants had thermostabilities which were significantly outside the normal range of $28.5 \pm 1.3 \mathrm{~min}$. These differences indicated that thermostability differences existed among the various electrophoretic classes. Additional studies also suggested that variants with differing thermostability profiles existed within several of the electrophoretic classes and indeed, when the various electrophoretic variants were re-electrophoresed at different $\mathrm{pH}$ 's, the four individuals which possessed the same slow (type 3) electrophoretic phenotype at $\mathrm{pH} 6.2$ were shown to differ electrophoretically at $\mathrm{pH} \quad 7 \cdot 5$.

The five electrophoretically distinct type 3 variants fell into two thermostability classes (Table 2). These enzymes were either as stable as or were more stable than the normal enzymes. Figure 4 illustrates the thermostability profile of the three cord blood samples in this group. Two of the electrophoretic variants in this group were detected in the Laboratory personnel samples, thus cord bloods were not available for study. Since significant activity and thermostability differences exist in GOT from non-cord blood samples (Fig. 3; Table 4), it becomes important to account for both the sex and the reproductive state of the individuals, consequently the activity and stability of these latter two samples were compared with the appropriate normal adult samples. 
Table 2. Thermostability classification of GOT variants

\begin{tabular}{|c|c|c|c|c|c|}
\hline Allele & Sample ID & $\begin{array}{l}\text { Stability } \\
\text { class } \\
\text { Cord }\end{array}$ & $\begin{array}{l}\mathrm{T} 0.5(\mathrm{~min}) \\
\text { d series }\end{array}$ & $\begin{array}{c}\mathrm{T} 0.5 \\
(\% \text { of normal) }\end{array}$ & Comment \\
\hline $2 \mathbf{A}-\mathbf{I}$ & 1904 & +++ & 28 & 98 & Normal \\
\hline \multirow[t]{3}{*}{$2 \mathrm{~A}-2$} & 973 & ++ & 18 & 63 & Less stable \\
\hline & 863 & ++ & 20 & 70 & Less stable \\
\hline & 1032 & $+t$ & 22 & 77 & Less stable \\
\hline $2 A-3$ & 2312 & + & 15 & 53 & Unstable \\
\hline \multirow[t]{2}{*}{$2 \mathrm{~B}-\mathrm{I}$} & 972 & $++t$ & $3^{I}$ & 109 & Normal \\
\hline & $195^{\circ}$ & $+t+$ & 30.5 & 107 & Normal \\
\hline $2 \mathrm{~B}-2$ & 535 & + & 145 & 51 & Unstable \\
\hline I (normal) & $(N=5)$ & $++t$ & $28 \cdot 5 \pm I \cdot 3$ & 100 & Normal \\
\hline $3 \mathrm{~B}$ & 763 & +++ & 25 & 88 & Normal \\
\hline $3 \mathrm{D}$ & 767 & ++++ & 40 & 140 & More stable \\
\hline $3 \mathrm{E}$ & 2148 & ++++ & 34 & 119 & More stable \\
\hline & \multicolumn{5}{|c|}{ Human Genetics miscellaneous samples } \\
\hline $3 \mathbf{A}$ & HG I I & +++ & - & 89 & Normal \\
\hline${ }_{3} \mathrm{~B}$ & HG 4 I & ++++ & - & I I 9 & More stable \\
\hline
\end{tabular}

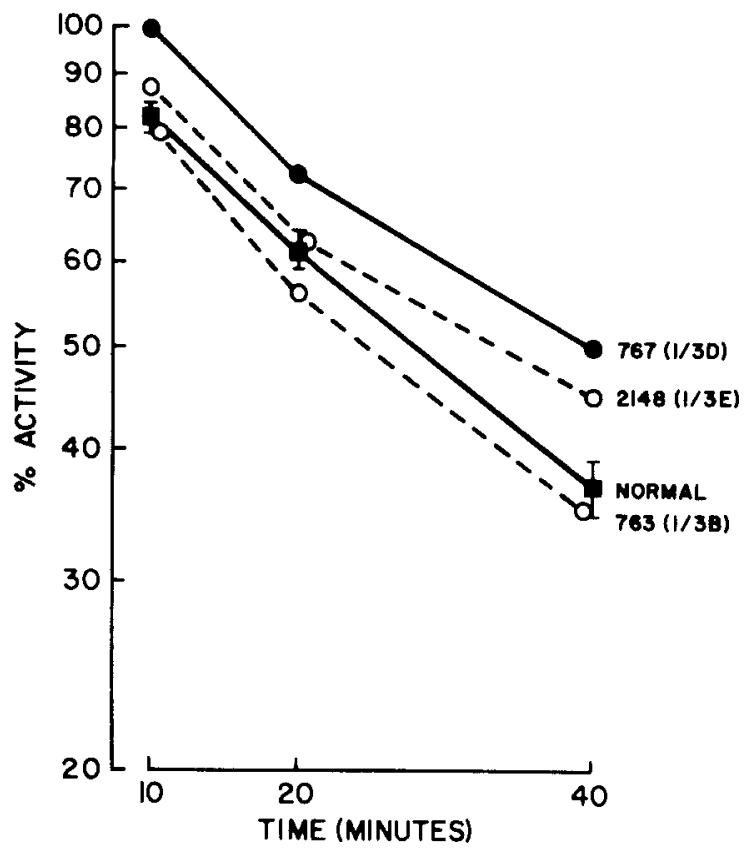

Fig. 4. Thermostability profiles at $67^{\circ} \mathrm{C}$ of type 3 variants from cord blood samples compared with the common phenotype.

The eight variants which were distributed between the two electrophoretically distinct type 2 variants fell into three thermostability classes (Table 2). Thermostability differences were apparent not only between but also within each of the two fast electrophoretic classes. Taken as a group, the $2 \mathrm{~A}$ variants are less stable than the $2 \mathrm{~B}$ variants. Three thermostability classes are recognized within the $2 \mathrm{~A}$ group (Fig. 5). Sample no. 973, which might well be placed into the $2 \mathrm{~A} 3$ class based on the cord blood thermostability profile was placed into the $2 \mathrm{~A} 2$ class based on the thermostability profile of enzyme from the affected parent. Two thermostability classes are recognized in the $2 \mathrm{~B}$ group (Fig. 6). 


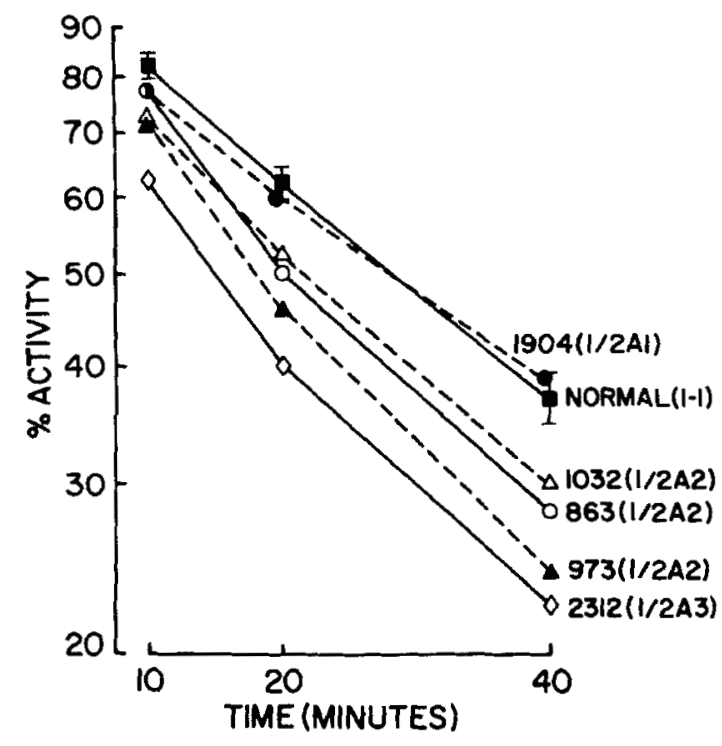

Fig. 5. Thermostability profiles at $67^{\circ} \mathrm{C}$ of the $1 / 2 \mathrm{~A}$ phenotypes from cord blood samples compared with the common phenotype.

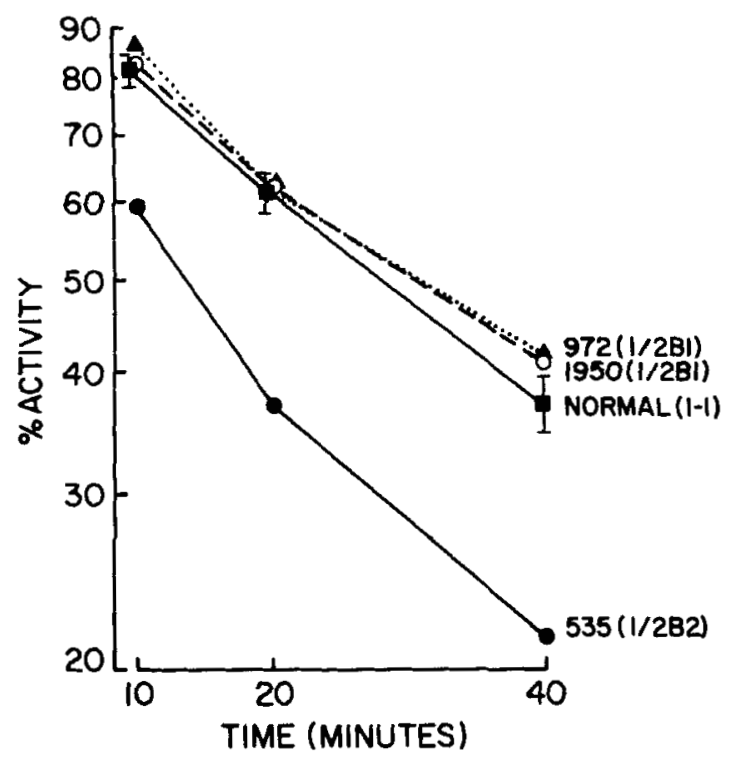

Fig. 6. Thermostability profiles at $67^{\circ} \mathrm{C}$ of the $1 / 2 \mathrm{~B}$ phenotypes from cord blood samples compared with the common phenotype.

Based on their thermostability profiles, the 13 GOT electrophoretic variants were placed into four different stability classes (Table 2). Two of the variants in two different electrophoretic classes were unstable, three variants in one electrophoretic class were less stable than normal, five variants in four different electrophoretic classes possessed normal stability and three different electrophoretic variants were more stable than normal. Family studies confirmed the inheritance of the electrophoretic as well as the thermostability variants (Table 3) except for variant $3 \mathrm{~A}$ where additional family members were not available. 
Table 3. Inheritance of GOT variants

\begin{tabular}{|c|c|c|c|c|c|}
\hline \multirow[b]{2}{*}{ Family } & \multirow{2}{*}{$\begin{array}{l}\text { Ethnic } \\
\text { group }\end{array}$} & \multirow{2}{*}{$\begin{array}{c}\text { Variant } \\
\text { allele }\end{array}$} & \multicolumn{3}{|c|}{ Family Phenotypes } \\
\hline & & & Mother & Father & Child \\
\hline HG-I I & Oriental & $3 \mathrm{~A}$ & - & $\mathrm{I} / 3 \mathrm{~A}$ & - \\
\hline 763 & Caucasian & $3 \mathrm{~B}$ & $1 / 1$ & $\mathbf{I} / \mathbf{3 B}$ & $\mathrm{I} / 3 \mathrm{~B}$ \\
\hline HG-4I & Caucasian & ${ }_{3} \mathrm{C}$ & $1 / 3 \mathrm{C}$ & $x / I$ & $1 / 3 \mathrm{C}$ \\
\hline 767 & Negro & $3 \mathrm{D}$ & $\mathrm{I} / 3 \mathrm{D}$ & $1 / 1$ & $1 / 3 \mathrm{D}$ \\
\hline 2148 & Negro & $3 \mathrm{E}$ & $1 / 3 \mathrm{E}$ & $1 / 1$ & $1 / 3 \mathrm{E}$ \\
\hline 1904 & Caucasian & $2 \mathrm{~A}_{\mathrm{I}}$ & $\mathrm{I} / \mathbf{2 A I}$ & $1 / 1$ & $1 / 2 A_{1}$ \\
\hline 973 & Oriental & $2 \mathrm{~A}_{2}$ & $1 / 1$ & $2 \mathrm{~A}_{2} / 2 \mathrm{Az}$ & $1 / 2 \mathrm{~A}_{2}$ \\
\hline 863 & Caucasian & $2 \mathrm{Al}_{2}$ & $\mathrm{I} / 2 \mathrm{A2}$ & $1 / 1$ & $1 / 2 A_{2}$ \\
\hline 1032 & Caucasian & $2 \mathrm{~A}_{2}$ & $\mathrm{I} / 2 \mathrm{A2}$ & $I / 1$ & $1 / 2 \mathrm{Az}_{2}$ \\
\hline 2312 & Caucasian & $2 \mathrm{~A}_{3}$ & $\mathrm{I} / 2 \mathrm{~A}_{3}$ & $1 / 1$ & $1 / 2 A_{3}$ \\
\hline 972 & Caucasian & $2 \mathrm{BI}$ & $1 / 1$ & $I / 2 B_{I}$ & $1 / 2 B_{1}$ \\
\hline 1950 & Caucasian & $2 \mathrm{BI}_{\mathrm{I}}$ & $\mathrm{I} / \mathbf{2 B} \mathrm{I}$ & $1 / 1$ & $\mathrm{I} / 2 \mathrm{BI}_{\mathrm{I}}$ \\
\hline 535 & Negro & $2 \mathrm{~B} 2$ & $\mathbf{I} / \mathbf{I}$ & $1 / 2 \mathrm{B2}$ & $\mathrm{I} / \mathbf{2 B 2}$ \\
\hline
\end{tabular}

Table 4. GOT activity in samples from individuals with normal electrophoretic phenotypes

$\begin{array}{lcc}\text { Sample type } & N & \text { Activity }(\bar{X} \pm \text { s.E. })^{*} \\ \text { Cords } & 8 & 5.76+0.29 \\ \text { Females } & & \\ \quad \text { Pregnant } & 9 & 4.49 \pm 0.51 \\ \quad \text { Non-pregnant } & 5 & 3.83 \pm 0.37 \\ \text { Males } & \text { I } 3 & 2 \cdot 86 \pm 0.23 \\ & * \mu \mathrm{m} / \mathrm{min} / \mathrm{g} \mathrm{Hb} .\end{array}$

\section{Activity differences}

Cord blood erythrocyte GO'T activity was $5 \cdot 76 \pm 0 \cdot 29$ units which is $1 \cdot 3$ times the activity in erythrocytes from pregnant females, 1.50 times the activity in non-pregnant females and $2 \cdot 0$ times the activity in males (Table 4). The level of enzymatic activity measured in the individuals with the variant phenotypes fell within the range of activity observed in the phenotypically normal individuals in the appropriate control groups and were similar to levels of activity previously reported (Beutler, 1975; Mohrenweiser, 1981; Mohrenweiser, Fielek \& Wurzinger, 1981), thus the in vitro lability observed during characterization of several of the variants is apparently not associated with an increased rate of enzyme degradation in the erythrocyte.

\section{DISCUSSION}

The differences in levels of erythrocyte GOT activity between cord and adult blood are usually explained in terms of differences in cell age. Young cells from either newborns or adults have been shown to have considerably higher GOT levels than old cells (Mohrenweiser et al. 1981; Sass, Vorsanger \& Spear, 1964; Gahr, Meves \& Schroter, 1979). The differences in erythrocyte GOT activity levels between pregnant families, non-pregnant females and males, however, is less easily explained. The differences between males and pregnant females undoubtedly reflect, at least partially, the almost universal vitamin supplementation of pregnant women in the population screened in this study. Dietary enrichment studies have shown that increased vitamin $B_{6}$ intake results not only in an increased activation of erythrocyte Apo-GOT, resulting 
in an increased percentage of enzymatically active protein, but also in an increased synthesis of the Apo-enzyme in young erythroid cells (Folkers, Watanabe \& Ellis, 1977; Solomon \& Hillman, 1979). This, however, may not necessarily explain the activity differences between males and non-pregnant females. One may hypothesize that a causal relationship lies in the hormonal differences between males and females. There is, however, no direct data to support this hypothesis although induction of this enzyme by hormones is known in experimental animals (Hurvitz \& Freedland, 1968; Gorin, Taylor \& Shafres, 1969). Inferences regarding a hormonal influence on erythrocyte GOT levels may perhaps be drawn from studies which show that oral contraceptives (oestrogen \& progesterone) taken in conjunction with oral supplementation of vitamin $B_{6}$ increases erythrocyte GOT levels to a greater degree than oral supplementation with vitamin $B_{6}$ alone, i.e. without concurrent oral contraceptive usage (Rose et al. 1972, 1973; Aly, Donald \& Simpson, 1971; Bosse \& Donald, 1979).

Differences in structure not demonstrable with electrophoretic techniques can often be detected as differences in thermostability as has been amply demonstrated for a variety of enzymes in various organisms (Singh, Hubby \& Lewontin, 1974; Bonhome \& Selander, 1978; Satoh \& Mohrenweiser, 1979; Mohrenweiser \& Neel, 1981). Thermostability differences, however, may also be a reflection of the physiological state of the individual, as is evidenced in the differences in the thermostability profile of erythrocyte GOT from males, non-pregnant females and pregnant females. This great difference in thermostability, as well as in levels of activity, may well reflect both the nutritional and the hormonal status of the individuals.

The cause of the greater thermostability of erythrocyte GOT from cord blood and pregnant females relative to males, and perhaps also non-pregnant females, in the presence of saturating levels of cofactor, is not known but may perhaps be due to a greater activation of enzyme during the heat treatment in the former group. Studies on cytoplasmic (as well as mitochondrial) GOT from other organisms indicate that, in addition to Apo- and Holo-GOT, there exists a considerable quantity of enzyme protein which binds pyridoxal phosphate in a catalytically inactive form (Martinez-Carrion et al. 1967; Banks et al. 1968; Magee \& Phillips, 1971). It is possible that the heating step results in an activation of this latter form of the enzyme which could result in an apparently thermostable enzyme.

No differences in the thermostability profile of GOT from cord blood and maternal erythrocytes were observed. Since pyridoxal-5-phosphate concentrations in maternal and cord blood are highly correlated (Lumeng, et al 1976; Ejderhamn \& Hamfelt, 1980) and since total (Apo- and Holo-) GOT levels are correlated with serum pyridoxal phosphate concentration (Hamfelt, 1967), the question arises as to whether the thermostability differences observed among the electrophoretic variants are solely a function of maternal nutritional status. Two pieces of information suggest that this is not correct. Firstly, several of the thermostability variants are paternal in origin. Secondly, the thermostability variants observed in the group of type 3 variants were shown to be electrophoretic variants when additional buffer systems were employed. Thus, although we realize that the thermostability profile of human erythrocyte GOT reflects both genetic and non-genetic influences, the data are sufficient to warrant sudividing the 2 electrophoretic classes of type 2 variants into 5 different genetic variants. This level of heterogeneity of 10 variant phenotypes occurring in 13 individuals in a sample of 2289 individuals is significantly higher than previously suggested and again indicates the need to utilize multiple techniques in studies of genetic variation. 
This work was supported by a contract from the Department of Energy (EY-77-C-02-2828).

\section{REFERENCES}

Aly, H. E., Donald, E. A. \& Simpson, M. H. W. (1971). Oral contraceptives and vitamin $B_{6}$ metabolism. Am. J. Clin. Nutr. 24, 297.

Ayala, F. J., Powell, J. B., Tracey, M. L., Mourao, C. A. \& Perez-Sal.as, S. (1972). Enzymatic variability in the Drosophila willistoni Group. IV. Genetic variation in natural populations of Drosophia willistoni. Genetics 70, 113.

Banks, B. E. C., Doonan, S., Lawrence, A. J. \& Vernon, C. A. (1968). The molecular weight and other properties of aspartate aminotransferase from pig heart muscle. Eur. J. Biochem. 5, 528.

Beutler, E. (1975). Red Cell Metabolism. A Manual of Biochemical Methods. Second edition, p. 160. New York: Grune \& Stratton.

Bonнomme, F. \& Selander, R. K. (1978). Estimating total genic diversity in the house mouse. Biochem. Genet. 16, 287.

Bosse, T. R. \& Donald, E. A. (1979). The vitamin $B_{6}$ requirement in oral contraceptive users. I. Assessment by pyridoxal level and transferase activity in erythrocytes. Am. J. Clin. Nutr. 32, 1015.

Brewer, G. J. (1970). An Introduction to Isozyme Techniques, p. 186. New York: Academic Press.

Chen, S.-H. \& GibletT, E. R. (1971). Genetic variation of soluble glutamic-oxaloacetic transaminase in man. Am. J. Hum. Gent. 23, 419.

Chen, S.-H., Malcolm, L. A., Yoshida, A. \& Giblett, E. R. (1971). Phosphoglycerate kinase: an X-linked polymorphism in man. Am. J. Hum. Genet. 23, 87.

Ejderhame, J. \& Hamfelt, A. (1980). Pyridoxal phosphate concentration in blood in newborn infants and their mothers compared with the amount of extra pyridoxal taken during pregnancy and breast feeding. Acta Paediatr. Scand. 69, 327.

Fielek, S. \& Mohrenweiser, H. W. (1979). Erythrocyte enzyme deficiencies assessed with a miniature centrifugal analyzer. Clin. Chem. 25, 384.

Folkers, K., Watanabe, T. \& Ellis, J. M. (1977). Studies on the basal specific activity of the glutamic oxaloacetic transaminase of erythrocytes in relationship to a deficiency of vitamin $\mathrm{B}_{6}$. Res. Commun. Chem. Path. Pharm. 17, 187.

Gahr, M., Meves. H. \& Schroter, W. (1979). Fetal properties in red blood cells of newborn infants. Pediat. Res. 13, 1231.

Gorin, E., Taylor, Z. \& Shafres, E. (1969). Glyceroneogenesis in adipose tissue of fasted, diabetic and triamcilnolone treated rats. Eur. J. Biochem. 8, $\mathbf{3 7 0 .}$

Hampelt, A. (1967). Pyridoxal phosphate concentration and aminotransferase activity in human blood cells. Clin. Chim. Acta 16, 19.

Hurvitz, A. I. \& Freedland, R. A. (1968). Influence of dietary protein on hydrocortisone-mediated adaptive enzymatic changes in rat liver. Biochem. Biophys. Acta 127, 548.

Ishimoto, G. \& Kuwata, M. (1974). Studies on human glutamic-oxaloacetic transaminase variation, including enzyme patterns in some non-human primates. Jap. J. Hum. Genet. 18, 364.

Jenkins, W. T., Yphantis, D. A. \& Sizer, I. W. (1959). Glutamic aspartic transaminase. I. Assay, purification, and general properties. J. Biol. Chem. 234, 51.

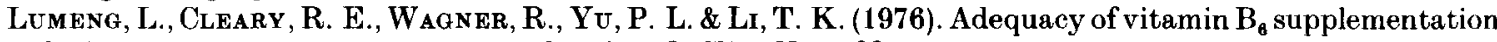
during pregnancy: a prospective study. Am. J. Clin. Nutr. 29, 1376.

Magee, S. C. \& Phillips, A. T. (1971). Molecular properties of the multiple asparate aminotransferases purified from rat brain. Biochemistry $10,3397$.

Martinez-Carrion, M., Turano, C., Chiancone, E., Bossa, R., Giartosio, A., Riva, F. \& Fasella, P. (1967). Isolation and characterization of multiple forms of glutamate-aspartate aminotransferase from pig heart. $J$. Biol. Chem. 242, 2397.

Mohrenweiser, H. W. (1981). Frequency of enzyme deficiency variants in erythrocytes of newborn infants. Proc. Natn. Acad. Sci., USA 78, 5046.

Mohrenweiser, H. W. \& Neel, J. V. (1981). Frequency of thermostability variants: estimation of total 'rare' variant frequency in human populations. Proc. Natn. Acad. Sci., USA 78, 5729.

Mohrenweiser, H. W., Fielek, S. \& Wurzinger, K. H. (1981). Characteristics of enzymes of erythrocytes from newborn infants and adults: activity, thermostability and electrophoretic profile as a function of cell age. Am. J. Hematol. 11, 125.

Nisselbaum, J.S. \& Bodansky, O. (1964). Immunochemical and kinetic properties of anionic and cationic glutamic-oxaloacetic transaminases separated from human heart and human liver. J. Biol. Chem. 239, 4232.

Poulik, M. D. (1957). Starch gel electrophoresis in a discontinuous system of buffers. Nature, Lond. $180,1477$. 
Rose, D. P., Strong, R., Adams, P. W. \& Hardina, P. E. (1972). Experimental vitamin $B_{6}$ defieiency and the effect of oestrogen containing oral contraceptives on tryptophan metabolism and vitamin $B_{6}$ requirements. Clin. Sci. 42, 465.

Rose, D. P., Strong, R., Folkard, J. \& Adams, P. W. (1973). Erythrocyte aminotransferase activities in women using oral contraceptives and the effect of vitamin $\mathrm{B}_{6}$ supplementation. Am. J. Clin. Nutr. $26,48$.

Sass, M. D., Vorsang ER, E. \& Spear, P. W. (1964). Enzyme activity as an indicator of red cell age. Clin. Chim. Acta 10, 21 .

Satoh, C. \& Mohrenweiser, H.W. (1979). Genetic heterogeneity within an electrophoretic phenotype of phosphoglucose isomerase in a Japanese population. Ann. Hum. Genet. $42,283$.

ScOTt, E. M. \& WRIGHT, R. C. (1981). An alternate method for demonstration of erythrocytic aminotransferases on starch gels. Am. J. Hum. Genet. 33, 561.

Selander, R. K., Smith, M. H., Yang, S. Y., Johnson, W. E. \& Gentry, J. B. (1971). Biochemical polymorphism and systematics in the genus Peromyscus. Univer. Texas Stud. Genet. 6, 49-90.

Singh, R., Hubby, J. L. \& Lewontin, R. C. (1974). Molecular heterosis for heat sensitive enzyme alleles. Proc. Natn. Acad. Sci., USA 71, 1808.

Solomon, L. R. \& Hillman, R. S. (1979). Regulation of vitamin $\mathrm{B}_{6}$ metabolism in human red cells. $A m$. $J$. Clin. Nutr. 32, 1824.

Tena, Y. S., Tan, S. G., Lopez, C. G., Ng, T. \& Lie-Injo, L. E. (1978). Genetic markers in Malaysians: variants of soluble and mitochondrial glutamic oxaloacetic transaminase and salivary and pancreatic amylase, phosphoglucomutase III and saliva esterase polymorphisms. Hum. Genet. 41, 347.

WA DA, H. \& MoRINo, Y. (1964). Comparative studies on glutamic oxaloacetic transaminases from the mitochondrial and soluble fractions of mammalian tissues. Vitamin Horm. 22, 411. 